\title{
Combined 22q11.1-q11.21 deletion with 15q11.2- q13.3 duplication identified by array-CGH in a 6 years old boy
}

Emmanouil Manolakos ${ }^{1 *}$, Catherine Sarri ${ }^{2}$, Annalisa Vetro ${ }^{3}$, Konstantinos Kefalas $^{1}$, Eleni Leze ${ }^{4}$, Christalena Sofocleus ${ }^{4}$, George Kitsos ${ }^{5}$, Konstantina Merou ${ }^{2}$, Haris Kokotas ${ }^{2}$, Anna Papadopoulou 6 , Achilleas Attilakos ${ }^{6}$, Michael B Petersen ${ }^{2}$ and Sofia Kitsiou-Tzeli ${ }^{4}$

\section{Correction}

The results section of the published article [1] state that the karyotype of the proband was defined as follows: 46, XY,ish der(22)t(15;22)(q11.2;q11.2)(TUPLE-,TBX-)mat.

The above definition contains an error and should instead be written as follows: 46,XY.ish der(15)(15pter\&gt;15q11.2::22q11.2-\&gt;22qter)t(15;22)(q11.2;q11.2) mat(TUPLE-,TBX1-).

\footnotetext{
Author details

'Bioiatriki S.A., Laboratory of Genetics, Athens, Greece. ${ }^{2}$ Department of Genetics, Institute of Child Health, St Sophia's Children's Hospital, Athens, Greece. ${ }^{3}$ Dipartimento di Patologia Umana ed Ereditaria, Universita di Pavia, Pavia, Italy. ${ }^{4}$ Department of Medical Genetics, Athens University School of Medicine, St Sophia's Children's Hospital, Athens, Greece. ${ }^{5}$ Department of Ophthalmology, University of loannina, loannina, Greece. ${ }^{6}$ Third Department of Pediatrics, University of Athens School of Medicine, Attikon University Hospital, Athens, Greece.
}

Received: 31 March 2011 Accepted: 16 April 2011 Published: 16 April 2011

\section{Reference}

1. Manolakos Emmanouil, Sarri Catherine, Vetro Annalisa, Kefalas Konstantinos, Leze Eleni, Sofocleus Christalena, Kitsos George, Merou Konstantina, Kokotas Haris, Papadopoulou Anna, Attilakos Achilleas, Petersen BMichael, Kitsiou-Tzeli Sofia: Combined 22q11.1-q11.21 deletion with 15q11.2-q13.3 duplication identified by array-CGH in a 6 years old boy. Molecular Cytogenetics 2011, 4:6.

\section{doi:10.1186/1755-8166-4-11}

Cite this article as: Manolakos et al:: Combined 22q11.1-q11.21 deletion with $15 q 11.2-q 13.3$ duplication identified by array-CGH in a 6 years old boy. Molecular Cytogenetics 2011 4:11.

\footnotetext{
* Correspondence: emanolakosgr@yahoo.gr
}

${ }^{1}$ Bioiatriki S.A., Laboratory of Genetics, Athens, Greece

Full list of author information is available at the end of the article

Submit your next manuscript to BioMed Central and take full advantage of:

- Convenient online submission

- Thorough peer review

- No space constraints or color figure charges

- Immediate publication on acceptance

- Inclusion in PubMed, CAS, Scopus and Google Scholar

- Research which is freely available for redistribution

\section{() Biomed Central}

C Biomed Central

(c) 2011 Manolakos et al; licensee BioMed Central Ltd. This is an Open Access article distributed under the terms of the Creative Commons Attribution License (http://creativecommons.org/licenses/by/2.0), which permits unrestricted use, distribution, and reproduction in any medium, provided the original work is properly cited. 